\title{
Pseudo-nitzschia fukuyoi (Bacillariophyceae), a domoic acid-producing species from Nha Phu Bay, Khanh Hoa Province, Vietnam
}

\author{
Ha Viet Dao ${ }^{1}$ Vy Bao Phan ${ }^{1}$ - Sing Tung Teng ${ }^{2}$ Hajime Uchida ${ }^{3}$ Chui Pin Leaw ${ }^{4}$. \\ Po Teen $\mathrm{Lim}^{4} \cdot$ Toshiyuki Suzuki ${ }^{3} \cdot$ Ky Xuan Pham ${ }^{1}$
}

Received: 9 January 2015 / Accepted: 21 February 2015 / Published online: 18 March 2015

(C) Japanese Society of Fisheries Science 2015

\begin{abstract}
Two strains of Pseudo-nitzschia fukuyoi isolated from Vietnamese waters produce domoic acid, a toxin responsible for amnesic shellfish poisoning. Species identification was based on detailed morphological observation using a transmission electron microscope and also molecular data on large subunit (LSU) and the second internal transcribed spacer (ITS2) with NCBI nucleotide Blast (blastn). Toxin productivity of the two strains was confirmed and their range were $3.85-4.54 \mathrm{pg} / \mathrm{cell}$ by analyses using LC-MS/MS. This is the first report of occurrence of $P$. fukuyoi in Vietnamese waters, and the first confirmation of productivity of domoic acid of the species.
\end{abstract}

Keywords Domoic acid - Amnesic shellfish toxin · Pseudo-nitzschia fukuyoi · Vietnam

\section{Introduction}

Species of the cosmopolitan genus Pseudo-nitzschia, some of which produce the neurotoxin domoic acid (DA), are often observed in tropical waters. Recently, several

Ha Viet Dao

daovietha69@gmail.com

1 Institute of Oceanography, Vietnam Academy of Science and Technology, 01 Cau Da, Nhatrang, Vietnam

2 Faculty of Resource Science and Technology, Universiti Malaysia Sarawak, Kota Samarahan, 94300 Sarawak, Malaysia

3 Tohoku National Fisheries Research Institute, 3-27-5 Shinhama, Shiogama, Miyagi 985-0001, Japan

4 Bachok Marine Research Station, Institute of Ocean and Earth Sciences, University of Malaya, 16310 Bachok, Kelantan, Malaysia potentially toxic Pseudo-nitzschia species were reported in the tropics, including Malaysia [1-5] and Vietnam [6, 7]. We recently documented that one of relatively small-sized species, $P$. cf. caciantha, from Nha Phu Bay, Khanh Hoa Province, Vietnam, was a DA producer [8]. Furthermore, we suspected that the species was most likely the source of the DA contamination in thorny oyster Spondylus versicolor in the bay. However, DA levels in plankton showed peaks in different seasons, which were around April [8] and August [9]. In the previous studies, during DA peak in plankton in August, DA producing species could not be detected successfully. Therefore, this study aims to investigate potential producers of DA in Nha Phu Bay in around August, with emphasis on species of the genus Pseudonitzschia using unialgal cultures established form the bay.

\section{Materials and methods}

\section{Sampling and algal cultures}

On 17 July 2013, 51 of seawater were collected at a site near Hon Thi Island, Nha Phu Bay $\left(12^{\circ} 38^{\prime} 42^{\prime \prime} \mathrm{N}\right.$, $109^{\circ} 22^{\prime} 06^{\prime \prime}$ E), Khanh Hoa Province, Vietnam, using a Van Dorn sampler from a 2-m depth. This sample was kept in the dark, without any preservative, and brought back to the laboratory for single-cell isolation.

Single cells of Pseudo-nitzschia species from the water sample were isolated using a fine-drawn Pasteur pipette under an inverted microscope (Nikon TMS-F MFA 20100). Cells were rinsed several times with $0.2 \mu \mathrm{m}$ filtered seawater before transferring into a 24-multiwell plate containing $1 \mathrm{ml}$ of $\mathrm{f} / 2$ medium [10] with $\mathrm{pH}$ of 7.8-8.0 at a salinity of 30. Cells that grew successfully were inoculated into $50 \mathrm{ml}$ culture flasks containing $30 \mathrm{ml}$ of $\mathrm{f} / 2$ medium, and finally 